\title{
Influence of quality relationship and satisfaction on loyalty: study on supplier in Indonesia
}

\author{
Dyah Sugandini \\ Universitas Pembangunan Nasional Veteran Yogyakarta Indonesia \\ Benny Wendry \\ Universitas Brawijaya Malang, Indonesia \\ Muafi \\ Universitas Islam Indonesia Yogyakarta, Indonesia
}

\begin{abstract}
Key words
Trust, involvement, commitment, quality, satisfaction and loyalty
\end{abstract}

\begin{abstract}
This study examined the nature of linkages between the quality relationship, satisfaction and customer loyalty. Furthermore, trust, commitment and involvement of product categories also tested to see its effect on the relationship quality. This study was conducted in a business-tobusiness setting of loyalty supermarket suppliers in Indonesia. The researchers employed 265 respondents of SMEs suppliers of vegetable and fruit in the supermarket as the sample. This research used Structural Equation Modeling (SEM) to analysis the relationship. The results revealed that the relationship quality and satisfaction effect on loyalty. The overall goodness of fit statistics shows that the structural model fits the data well.
\end{abstract}

Corresponding author: Dyah Sugandini

Email address for corresponding author:diah_sugandini@yahoo.com

First submission received: 6th February 2017

Revised submission received: 10th March 2017

Accepted: 23rd March 2017

\section{Introduction}

Relationship Marketing is an effort to attract customers and improve customer relationships. Relationship Marketing is an attempt to know consumers better, so the company can meet the needs and desires of its customers. Grönroos (1991), looked at the relationship marketing as an effort to develop, maintain, improve and commercialize relationships with customers in order to realize the objectives of all parties involved. Gummesson (1999), defines relationship marketing as a continuation of the mutual relationship between a service provider and a customer who will lead to formation of profitability. The basic philosophies of relationship marketing are based on the assumption that company-customer interactions and strategies can earn and keep the loyalty of customers (Berry, 1995). This study discusses the relationship of loyalty between suppliers and companies in the supply chain cycle. This study analyzes the loyalty of the supplier side.

Loyalty in question is the loyalty of suppliers to continue to be loyal to the company, so that these suppliers will not switch to another company. Initial research conducted by researchers showed that SMEs suppliers of vegetable and fruit have a tendency to move and are not loyal to a supermarket. Geyskens \& Steenkamp (2000), empirically found that loyalty is the result of economic satisfaction and a channel member's evaluation of the economic outcomes that flow from the relationship with its partner such as volume, margins and bonus. This phenomenon occurs almost throughout the supermarket supplier in Indonesia. This study differs from some of the research 
conducted by previous researchers with a B2B setting that analyzes loyalty from the consumer side or the side of the company (Ryssel, Ritter \& Gemunden, 2004, Eng, 2004., Woo \& Ennew, 2004).

The importance and benefits of attracting and maintaining loyal customers has arisen because there is a general acceptance that profitability follows customer loyalty (Reichheld \& Sasser 1990). The economic value of loyalty has been discussed by Jone \& Sasser (1995) and Reichheld (1996). Therefore, complete understanding of the concept of loyalty highlights the need for a balance of value between customers and the firm and the need to develop customer loyalty as a long term investment. Shani \& Chalasani (1993), defines the relationship of loyalty as an effort to develop an ongoing relationship with customers in relation to a series of related products and services. Morgan \& Hunt (1994), formulate loyalty relationship as all marketing activities directed at building, developing, and maintaining successful relational exchanges.

\section{Research Purposes}

This study aims to provide a model of how relationship quality and satisfaction can influence customer loyalty in the business-to-business context. Based on previous research, we propose relationship quality as a higher construct comprising, trust, involvement product categories, and commitment. The effect of trust, involvement product categories and commitment will be tested as well in this study.

\section{Literature review and Hypothesis Loyalty}

Customer loyalty represents a commitment to do business with the organization, with the purchase of goods and services repeatedly, and recommend services and products to your friends and groups (McIlroy \& Barnett, 2000). Prior studies confirm that service companies have received incredible benefits of loyal customers (Bagherzad, Chavosh, \& Hosseinikhah, 2011). Yim, David \& Chan (2008), defined customer loyalty as a highly deep commitment to keep on purchasing a product or service in the future regardless of the fact that there are situational factors and marketing efforts, which have been potential to create switching behaviour.

\section{Trust}

Customer trust can be defined as a set of beliefs held by an online consumer concerning certain characteristics of the e-supplier, as well as the possible behaviour of the supplier in the future (Coulter \& Coulter, 2003). Trust is an important indicator of relationship quality (Muafi, 2016; 2015). Only when a person trusts the trustee will he/she be likely to perceive that there is a high quality relationship between the trustee and him/her. A relationship that lacks trust is unlikely to be perceived as of high quality. It is also important to note that trust is difficult to foster, can be shaken easily, and once shaken, is extremely difficult to rebuild (Shneiderman, 2000; Muafi, 2016; 2015).

$H_{1}$ : Trust has an influence on quality relationship.

\section{Involvement product category}

Involvement originates from social psychology and the notion of "ego involvement," which refers to the relationship between an individual and an issue or object. Involvement product categories involve an ongoing commitment on the part of the consumer with regard to thoughts, feelings, and behavioural response to a product category (Miller \& Marks, 1996; Gordon et al., 1998). Involvement product category is consumer perception of the product categories of interest based on the needs, values and interests (Mittal, 1995). DeWulf, et al. (2001), stated that the high level of involvement of products will affect the quality relationships.

$\mathrm{H}_{2}$ : Involvement product category has influence on quality relationship.

\section{Commitment}

Commitment defined as the enduring desire to maintain a valued relationship (Palmatier et al., 2006), customer commitment is one of the most commonly studied key determinants in 
relationship quality studies (Hsieh \& Kai, 2008). Ndubisi et al. (2007) stated that the commitment of the company can be addressed with a continuous learning by providing customer needs and service quality to increase customer satisfaction, which in turn will bring the company to the creation of a close relationship with its customers.

\section{$\mathrm{H}_{3}$ : Commitment has influence on quality relationship}

\section{Quality Relationship}

Quality Relationship refers to the overall assessment of the strength of a relationship between two parties (Palmatier et al., 2006). Drawing upon the marketing literature, relationship quality has emerged as a paradigm that indicates the extent that the customer trusts the service provider and has confidence in the service provider's future performance because the provider's past performance has been consistently satisfactory. Hennig-Thurau and Klee (1997), stating that relationship quality is the antecedent of repeat purchase behaviour.

\section{$\mathrm{H}_{4}$ : Quality relationship has influence on loyalty.}

\section{Satisfaction}

Sugandini (2002), states that customer satisfaction and service quality are prerequisites of customer loyalty. Satisfaction can be described as an evaluation of the perceived discrepancy between prior expectation and the actual performance of the product (Oliver, 1999). Customer satisfaction is important because satisfied customers are less likely to switch to a competitor (Kotler, 2002). According to Doyle (2002), a highly satisfied customer will exhibit the following characteristics: (1) stays in loyal longer, (2) buys more, (3) talks favorably about the company, (4) pays less attention to competing brands and advertising, and (5) the company will cost less to serve than new customers. Dick \&Basu (1994) and Oliver (1999), suggest satisfaction to be an affective antecedent of brand loyalty. Satisfaction is often thought to affect the likelihood of repurchasing or reusing the service of a provider. Oliver et al. (1997), propose three dimensions of satisfaction; cognitive, affective and conative, that culminates in action loyalty or repeat usage.

$\mathrm{H}_{5}$ : Satisfaction has influence on loyalty.

Based on the theory and evidence of past research on loyalty, it is possible propose the following research issues: whether the relationship quality and satisfaction effect on supplier loyalty? The hypothesis is based on previous studies may be described in the model in Figure 1.

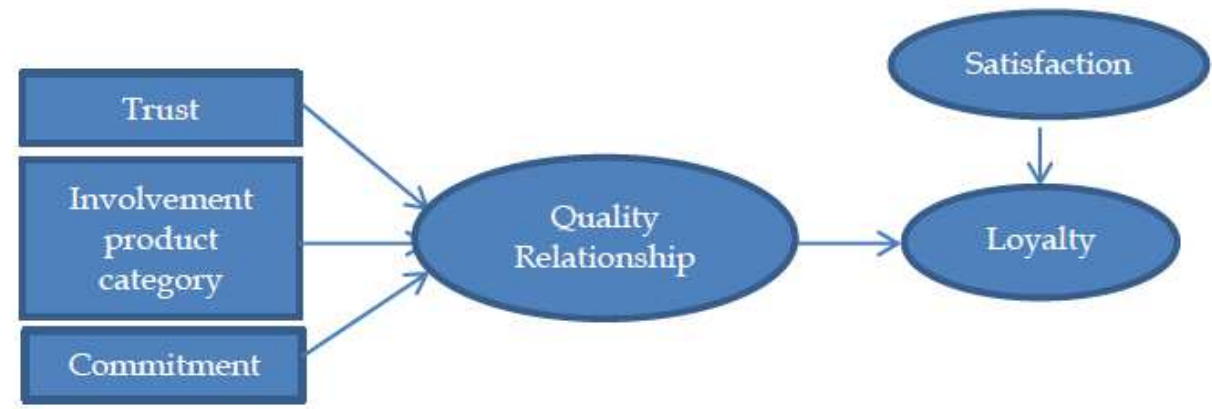

Figure 1: Structural model of quality relationship and satisfaction as predictor of loyalty

\section{The Research Methodology}

Based on the literature review and previous works, a survey questionnaire was made by the researchers consisting of (28) questions about the respondents and their perception of the level of trust, involvement product category, commitment, quality relationship, satisfaction and loyalty from SMEs vegetable and fruit into supermarket supplier in Indonesia. The survey questionnaire utilized constructs measure using multiple items, and all of the scale items represented in the survey instrument utilized a five-point categorical rating scale. The questionnaire consisted of two parts. The first part included customers' demographic characteristics, including the length of a supplier, 
gender, age, and education level. Sample distributed of 350 SMEs suppliers of vegetable and fruit in Indonesia's supermarket. The questionnaire was administered mail post and face-to-face to the suppliers. The total number of returned questionnaires was 300 in a response rate of $88 \%$. Among the collected questionnaires, 35 have missed responses resulted in 265 usable questionnaires.

\section{Discussions and conclusions}

In this study, a two steps approach (Anderson \& Gerbing 1988), was selected for measurement model and structural model. The results also show that all measurement models of relationship dimensions achieved a satisfactory level of fit to the data. The hypothesized relationships were estimated using structural equation modeling. The overall goodness of fit statistics shows that the structural model fits the data well. The evaluation of the test results of the model can be seen in Table 1 .

Table 1. Goodness-of-fit measures for SEM

\begin{tabular}{|l|c|c|c|}
\hline \multicolumn{1}{|c|}{ Fit measures } & Result & Critical value* & Evaluation Model \\
\hline Cmin/DF & 2,270 & $1 \leq$ Normed $\chi^{2} \leq 5$ & Good \\
\hline Probability & 0,065 & $\geq 0,05$ & Good \\
\hline RMSEA & 0,087 & $\leq 0,08$ & Moderate \\
\hline GFI & 0,994 & $\geq 0,90$ & Good \\
\hline TLI & 0,975 & $\geq 0,95$ & Good \\
\hline CFI & 0,998 & $\geq 0,94$ & Good \\
\hline
\end{tabular}

From the table above it can be argued that the model is acceptable. lo test the hypothesis of a causal relationship between trust, involvement product category, commitment, quality relationship, customer satisfaction and loyalty, following the path coefficients are presented that show a causal relationship between these variables. The relationships are shown in Table 2.

Table 2. Parameter estimates, $t$-value, and results of hypotheses

\begin{tabular}{|l|c|c|c|c|}
\hline Hypothesized path & $\begin{array}{c}\text { Standardized } \\
\text { estimate }\end{array}$ & CR & Probability (p) & $\begin{array}{l}\text { Result of } \\
\text { hypotheses }\end{array}$ \\
\hline Trust $\rightarrow$ Quality Relationship & 0.249 & 13.581 & 0.013 & Supported \\
\hline Involvement $\rightarrow$ Quality Relationship & 0.716 & 8.635 & 0.000 & Supported \\
\hline Commitment $\rightarrow$ Quality Relationship & 0.310 & 10.495 & 0.035 & Supported \\
\hline Quality Relationship $\rightarrow$ Loyalty & 0.327 & 6.635 & 0.007 & Supported \\
\hline Satisfaction $\rightarrow$ Loyalty & 0.290 & 6.930 & 0.013 & Supported \\
\hline
\end{tabular}

Testing the hypothesis (alternative) is done by comparing the probability value (p). Probability value $(p)$ is said to be significant if the $p$ value $p \leq 0.05$. With this criteria look that all paths is significant. That is to say, trust significant positive effect on relationship quality. Involvement product category has significant positive effect on relationship quality, commitment significant positive effect on relationship quality, relationship quality significant positive effect on loyalty. Satisfaction has significant positive effect on loyalty. From the results of testing the significance of each variable and its indicators, the five hypotheses can be accepted. This show that companies that want to create loyalty from its suppliers must be able to prioritize involvement with the product category suppliers, because of the involvement in the product category has the greatest effect on the quality of the relationship. In addition, a commitment which was built by the company on its suppliers must also be respected together. The quality of supplier relationships and supplier satisfaction need to be improved in order to increase the loyalty of these suppliers so that he was not easy to leave the company.

\section{Research limitations and direction for further research}

This study confirms the importance of customer loyalty. In the supermarket industry or retail industry in general, where the supplier is needed by the company. Given the success of supply chain 
management is also influenced by its suppliers. Relationship loyalty not only makes a plat form where the customer is ready to stay the maximum time with the organization and causes long-term benefit, but also provides an inspiration with the company products or services. It is important to Supermarket to optimize the relationship quality and satisfaction. This study supports the results of research conducted by Crosby et al. (1990); Moorman et al. (1992; Muafi, 2016; 2015), who argue that most of the relationship quality research provided three primary dimensions: trust, commitment and satisfaction. De Wulf et al. (2001), stated that the high level of involvement of products will affect the quality of relationships. This study provides further opportunities for researchers to conduct research on the retail industry, such as hotel and restaurant. Other variables that can affect customer loyalty as the company's image, service quality and switching barriers can be added to be analyzed, in addition to relationship quality and satisfaction. Finally, this study recommended is expected to be given an understanding of consumer loyalty.

\section{References}

Anderson, J. C. and Gerbing, D.W. (1988), “Structural equation modelling in practice: a review and recommended two-step approach",Psychological Bulletin, Vol.130 (3),pp. 411-23.

Bagherzad, A.,Chavosh, A and Hosseinikhah, S. (2011), "The influence of relationship marketing tactics on customer's loyalty in B2C relationship-the role of communication and personalization", European Journal of Economics, Finance and Administrative Sciences, Vol. 5(31), pp. 49-56.

Berry, L. (1995), "Relationship marketing of services-growing interest, emerging perspectives", Journal of the Academy of Marketing Science, Vol.23 (4), pp. 236-45.

Coulter, K.S. and Coulter, R.A. (2003), "The effects of industry knowledge on the development of trust in service relationships", International Journal of Research in Marketing, Vol.20(1), pp. 31-43.

Crosby, L.A., Kenneth R.E, and Deborah, C. (1990), "Relationship quality in services selling: An interpersonal influence perspective", Journal of Marketing, Vol.54 (July), pp. 68-81.

DeWulf, K., Schroder, G.O. and Iacobucci, D. (2001), “Investments in consumer relationships: acrosscountry and cross-industry exploration", Journal of Marketing, Vol.65(4), pp. 33-50.

Dick, A.S. and Basu, K. (1994), "Customer loyalty: toward an integrated conceptual framework", Journal of the Academy of Marketing Science, Vol.22 (2), pp. 99-113.

Doyle, P. (2002), Marketing Management and Strategy, $3^{\text {rd }}$ ed. London: Prentice Hall International.

Eng, Teck-Yong. (2004), "Does customer portfolio analysis relate to customer performance? An empirical analysis of alternative strategic perspective," The Journal of Business \& Industrial Marketing, Vol.19 (1), pp. 49.

Geyskens, I.and Steenkamp, J-B.E.M. (2000), “Economic and social satisfaction: Measurement and relevance to marketing channel relationships", Journal of Retailing, Vol.76 (Spring), pp. 11-32

Gordon, M.E.,McKeage, K., and Fox, M.A. (1998), "Relationship marketing effectiveness: The role of involvement",Psychol. Mark, Vol. 15(5), pp. 443- 459.

Gronroos, C. (1991), "From marketing mix to relationship marketing: Toward a paradigm shift in marketing", Journal of Management Decision, Vol. 32 (2), pp. 4-20

Gummesson, E. (1999), Total Relationship Marketing - Rethinking Marketing Management: From 4PS To 30S, Butterworth: Heinermann.

Hennig-Thurau., T and Klee, A. (1997), "The impact of customer satisfaction and relationship quality on customer retention: A critical reassessment and model development",Psychology and Marketing, Vol. 14 (8), pp. 737-64.

Hsieh, An-Tien.Li.and Chung-Kai. (2008), "The moderating effect of brand image on public relations perception and customer loyalty", Marketing Intelligence \& Planning, Vol. 26 (1), pp. 26-42

Jones, T.O. and Sasser, E.Jr. (1995), "Why satisfied customers defect", Harvard Business Review, (NovDec), pp. 88-99. 
Kotler, P. (2002), Marketing Management, An Asian Perspective, 3 ${ }^{\text {th }}$ Edition, Prentice Hall, Pearson Education Asia Pte. Ltd., Singapore.

Mcllroy, A and Barnett, S. (2000), "Building customer relationships: do discount cards work?,Managing Service Quality, Vol. 10 (6), pp. 347-355.

Miller D.W. and Marks, L.J. (1996), "The moderating effects of enduring involvement on imagery evoking advertisements".American Marketing Association, pp. 121-128.

Mittal, B (1995), "A comparative analysis of four scales of consumer involvement",Psychology $\mathcal{E}$ Marketing,Vol. 12 (7), pp. 663-682.

Moorman, C., Zaltman, G. and Deshpande, R. (1992), "Relationships between providers and users of market research: the dynamics of trust within and between organisations", Journal of Marketing Research, Vol.24 (August), pp. 314-28.

Morgan, R.M. \& Hunt, S.D. (1994), "The commitment-trust theory of relationship marketing”, Journal of Marketing, Vol.58(3), pp. 20-38.

Muafi (2016), Analyzing Fit in CSR Strategy Research in State-Owned Enterprises: Indonesia Context, Journal of Industrial Engineering and Management, 9(1): p. 179-206.

Muafi., 2015, Green IT Empowerment, Social Capital, Creativity and Innovation: A Case Study of Creative City, Bantul, Yogyakarta, Indonesia, Journal of Industrial Engineering and Management, Vol. 8, No. 3, p. 719-737.

Ndubisi, N.O. (2007), "Relationship marketing and customer loyalty", Marketing Intelligence $\mathcal{E}$ Planning, Vol. 25 (1), pp. 98-106.

Ndubisi, N.O., Chan, K.W. andGibson, C.N. (2007), "Supplier-customer relationship management and customer loyalty: the banking industry perspective", Journal of Enterprise Information Management, Vol. 20(2), pp.222-236.

Oliver, R.L., Rust, R. andVarki, S. (1997), “Customer delight: foundations, findings, and managerial insight", Journal of Retailing, Vol.73 (3), pp. 311.

Oliver, R.L. (1999), "When consumer loyalty?",Journal of Marketing, Vol. 63 (special issue), pp. 33-44.

Palmatier, R.W., Rajiv P.D., Grewal, D. and Evans, K.R. (2006), "Factors Influencing the effectiveness of relationship marketing: A meta-analysis", Journal of Marketing, Vol. 70 (4), pp. 136-153.

Reichheld, F.F. (1996), “Learning from customer defections”,Harvard Business Review, Vol.74 (2), pp. 56.

Reichheld, F.F. and Sasser,W.E.Jr. (1990), "Zero defections: quality comes to services",Harvard Business Review, Vol. 68 (5), 105.

Ryssel, R., Ritter, T and Gemunden, H.G. (2004), "The impact of information technology deployment on trust, commitment and value creation in business relationships", The Journal of Business $\mathcal{E}$ Industrial Marketing, Vol. 19 (3), pp. 197.

Shani, D. and Chalasani, S. (1993), "Exploiting niches using relationship marketing", Journal of Business \& Industrial Marketing, Vol. 8 (4), pp.58 - 66.

Shneiderman, B. (2000), "Designing trust into online experiences", Communications of The Acm,Vol.43 (12), pp. 57-59.

Sugandini, D, (2003), “Anteseden loyalitas konsumen pada industry perhotelan (Studi pada hotel berbintang di Daerah Istimewa Yogyakarta)", Wahana, Vol. 6 (2), pp. 181-200.

Woo, Ka-shing and Ennew. C.T. (2004), "Business-to-business relationship quality: an IMP interaction-based conceptualization and measurement",European Journal of Marketing, Vol.38 (9/10), pp. 1252.

Yim, C.K., David, K. and Chan, K.W. (2008), “Strengthening customer loyalty through intimacy and passion: roles of customer-firm affection and customer-staff relationships in services", Journal of Marketing Research, Vol.45 (6), pp. 741- 756. 